\title{
Hypoxia-induced habitat shifts and energetic consequences in Atlantic croaker and brown shrimp on the Gulf of Mexico shelf
}

\author{
J. Kevin Craig ${ }^{1,2, *}$, Larry B. Crowder ${ }^{1}$ \\ ${ }^{1}$ Nicholas School of the Environment and Earth Sciences, Duke Center for Marine Conservation, 135 Duke Marine Lab Rd., \\ Beaufort, North Carolina 28516-9721, USA \\ ${ }^{2}$ Center for Marine Sciences and Technology, North Carolina State University, 303 College Circle, Morehead City, \\ North Carolina 28557, USA
}

\begin{abstract}
Seasonal, summertime hypoxia (dissolved oxygen $\leq 2 \mathrm{mg} \mathrm{l}^{-1}$ ) has occurred over large areas ( 1000 to $\left.20000 \mathrm{~km}^{2}\right)$ of the northwestern Gulf of Mexico shelf during several years since at least the mid-1980s, resulting in habitat loss for demersal species. To evaluate the effects of hypoxiainduced habitat loss on Atlantic croaker Micropogonias undulatus and brown shrimp Farfantepenaeus aztecus, we compared species' spatial distributions and relationships to abiotic factors (temperature, dissolved oxygen, salinity) across years differing in the spatial extent of hypoxia. Analysis of $14 \mathrm{yr}$ of fishery-independent research trawl and environmental data (July) indicated that hypoxiainduced shifts in spatial distribution result in considerable shifts in the temperature and oxygen conditions that croaker and brown shrimp experience. Croaker, which typically occupy relatively warm, inshore waters, remain in the warmest waters inshore of the hypoxic region but also are displaced to cooler offshore waters. Brown shrimp, which are typically distributed more broadly and further offshore, shift to relatively warm inshore waters as well as cooler waters near the offshore hypoxic edge. These shifts in the species' spatial distribution are reflected in long-term decreases and increases in the mean temperatures occupied by croaker and brown shrimp, respectively, as well as increases in the variance in occupied temperatures for both species. Despite avoidance of the lowest oxygen waters, high densities of croaker and brown shrimp occur in areas of moderately low oxygen concentration (35 to $60 \%$ air saturation, 1.6 to $3.7 \mathrm{mg} \mathrm{l}^{-1}$ ) near the offshore hypoxic edge. Because temperature and dissolved oxygen are important abiotic factors that impact metabolic scope, these shifts in spatial distribution during severe hypoxia may impact organism energy budgets. High croaker and shrimp densities near the hypoxic edge likely have implications for trophic interactions as well as the harvest of both target (brown shrimp) and nontarget (croaker) species by the commercial shrimp fishery.
\end{abstract}

KEY WORDS: Hypoxia · Micropogonias undulatus · Farfantepenaeus aztecus · Gulf of Mexico · Bioenergetics $\cdot$ Abiotic factors $\cdot$ Spatial distribution $\cdot$ Edge effects

\section{INTRODUCTION}

Low dissolved oxygen (hypoxia, $\leq 2 \mathrm{mg} \mathrm{l}^{-1}$; anoxia, $\leq 1 \mathrm{mg} \mathrm{l}^{-1}$ ) associated with eutrophication arising from altered coastal nutrient budgets is an important stressor of aquatic ecosystems (Caddy 1993, Diaz \& Rosenberg 1995, NRC 2000). The northwestern Gulf of Mexico continental shelf currently experiences one of the largest seasonal hypoxic regions in the world (Rabalais et al. 2002). Bottom oxygen deficits arise from physical and biological processes associated with nutrient and freshwater loading from the Mississippi-Atchafalaya River system, which ranks among the top 10 rivers in the world in freshwater and sediment discharge, as well as drainage basin area (Rabalais \& Turner 2001, Rabalais et al. 2002). Hypoxic bottom waters typically 
occur from 5 to $30 \mathrm{~km}$ from shore at depths of 5 to $30 \mathrm{~m}$. The vertical extent of hypoxia in the water column is generally restricted to the bottom few meters, but at times may occupy as much as 50 to $80 \%$ of the water column (Rabalais \& Turner 2001). Hypoxia is most intense from June to August but has been detected as early as February and as late as October. Though the spatial and temporal dynamics of the hypoxic region over the summer months is not well known, large areas are believed to remain hypoxic for extended periods in the absence of storm-induced mixing events (Rabalais et al. 2002, Craig et al. 2005). Since mapping began in the early-mid-1980s, the estimated area of hypoxia has varied from effectively zero to $>21000 \mathrm{~km}^{2}$, with several years of normoxia or moderate hypoxia during the 1980 s to early 1990 s (mean area $\sim 7000 \mathrm{~km}^{2}$, range $\sim 0$ to $\sim 12000 \mathrm{~km}^{2}$ ), several consecutive years of severe hypoxia in the mid- to late 1990s (mean area $\sim 16000 \mathrm{~km}^{2}$, range $\sim 13000$ to $\sim 17000 \mathrm{~km}^{2}$ ), and considerable annual variation in the area of hypoxia in more recent years (range $\sim 4000$ to $\sim 21000 \mathrm{~km}^{2}$ ) (Rabalais et al. 2002, Craig et al. 2005).

Low dissolved oxygen can have a variety of physiological and ecological effects on aquatic organisms. While laboratory studies indicate low oxygen impacts individual movement, growth, and mortality (Wannamaker \& Rice 2000, Taylor \& Miller 2001, Wu 2002), effects at the cohort or population level have been difficult to demonstrate. In part, this is because exposure to low oxygen is often ephemeral for mobile species due to avoidance behavior, so that hypoxia effects are likely indirect and associated with habitat loss and shifts in spatial distribution (Coutant 1985, Pihl et al. 1991, Brandt \& Mason 2003). Indirect effects of hypoxia on trophic interactions can be positive or negative depending on trophic level and speciesspecific details of foraging and predation processes (e.g. Breitburg et al. 1999, Taylor \& Eggleston 2000, Seitz et al. 2003). Finally, hypoxia effects may co-occur with other effects of eutrophication (e.g. increased productivity) and environmental change that potentially induce tradeoffs that occur across life history stages (Micheli 1999, Grimes 2001, Breitburg 2002).

Dissolved oxygen and temperature have important effects on the energy budgets of aquatic organisms. Ambient dissolved oxygen sets the maximum rate at which oxygen can be supplied to tissues in support of functions above standard metabolism, limiting metabolic scope and the performance of aquatic organisms (Fry 1971, Priede 1985). For most organisms, a minimum level of dissolved oxygen exists below which metabolism is dependent on ambient oxygen concentration (incipient limiting level; Fry 1971, Bridges \& Brand 1980). When ambient oxygen levels decline, oxygen consumption can be maintained by a variety of compensatory processes, though these presumably entail some energetic costs ( $\mathrm{Wu} 2002$ ). At some low level of dissolved oxygen, however, metabolic pathways associated with the production or use of energy are suppressed, leading to a reduction in metabolic scope and energy available for growth and other activities (Claireaux et al. 2000, Lefrancois \& Claireaux 2003).

Within the limits imposed by dissolved oxygen, temperature controls the metabolic rate and, hence, the energy available after standard metabolic costs have been met (Fry 1971). Fish can discriminate small differences in temperature and generally have well-defined temperature preferences (Brett 1971, Magnuson et al. 1979), often near those that maximize one or more components of fitness such as growth rate (Jobling 1981) or swimming ability (Brett 1971, Bryan et al. 1990). Temperature may influence reproduction directly through the rate of gonadal maturation and synthesis (Bergström 1991), or indirectly via effects on somatic growth and associated body size and maturation (Cripe 1994, Hutchings \& Myers 1994). Likewise, temperature may impact foraging rates and, hence, prey mortality rates, particularly if predation is sizedependent (Taylor \& Collie 2003).

Based on fishery landings and effort data, Diaz \& Solow (1999) found a negative relationship between annual brown shrimp Farfantepenaeus aztecus catch-per-unit-effort (landed weight $\mathrm{d}^{-1}$ fished) and an index of hypoxia in the Gulf of Mexico suggestive of a negative effect of hypoxia on shrimp production. The mechanism(s) underlying the observed correlation are unknown but may include decreases in growth, increases in mortality, or changes in fishing patterns associated with hypoxia. They cautioned against assuming this correlative relationship was caused by hypoxia, however, due to secular trends in the time series, the weakness of the correlation, and other data issues.

Hypoxia on the Louisiana shelf typically occurs in regions of historically high demersal fish and crustacean biomass (Moore et al. 1970, Darnell et al. 1983). Based on data from the 1960s, when hypoxia was likely nonexistent or more limited in spatial extent, juvenile Atlantic croaker Micropogonias undulatus were found primarily in shallow water (within the $20 \mathrm{~m}$ depth contour) while sub-adult brown shrimp were broadly distributed with peak densities slightly further offshore ( 20 to $30 \mathrm{~m}$ depth) (Darnell et al. 1983). Areas of historically high density for both species, however, are well within the recent spatial extent of hypoxia. We have previously shown that hypoxia results in extensive habitat loss and shifts in spatial distribution for both species (Craig 2001, Craig et al. 2001, 2005). In this paper we use data from fishery-independent research trawl surveys from 1987 to 2000 to test the 


\section{A. 1987 croaker}

Fig. 1. Micropogonias undulatus and Farfantepenaeus aztecus. Examples of the distribution of croaker and brown shrimp during $(\mathrm{A}, \mathrm{B})$ moderate hypoxia and $(C, D)$ severe hypoxia. Heavy lines encompass area where bottom dissolved oxygen $\leq 2.0 \mathrm{mg}$ $\mathrm{l}^{-1}$. Crosses are stations where no croaker (or brown shrimp) were caught. Circle sizes are proportional to the magnitude of croaker (or brown shrimp) catch rates and represent the quartiles of the catch rate distribution

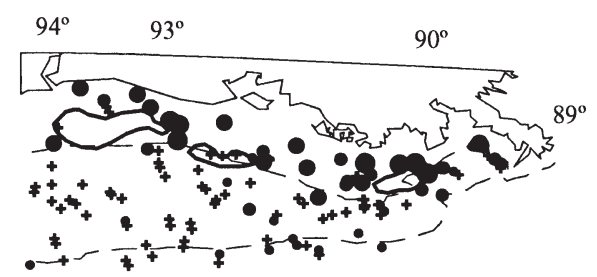

\section{1997 croaker}

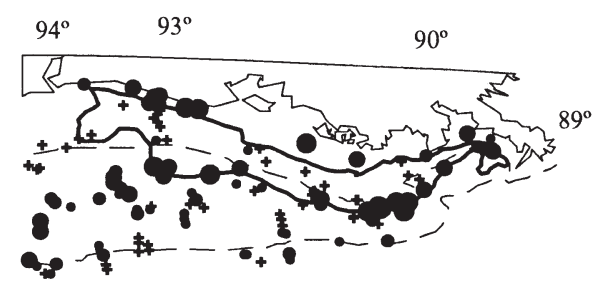

B. 1987 shrimp

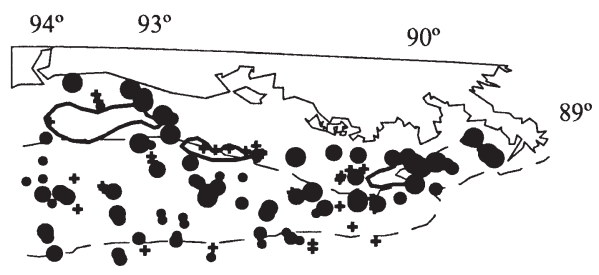

D. 1997 shrimp

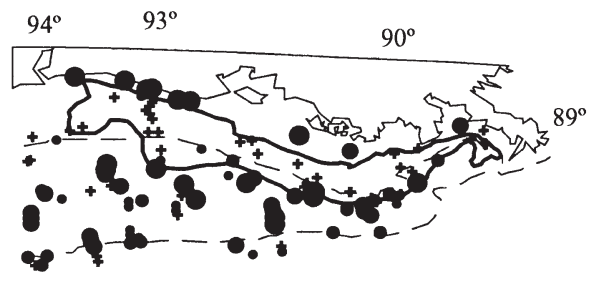

hypothesis that hypoxia-induced habitat loss results in shifts in energetically important abiotic conditions (e.g. temperature, dissolved oxygen, salinity) experienced by croaker and brown shrimp as a consequence of low oxygen avoidance behavior and movement to alternative habitats on the shelf (Fig. 1). We also test the hypothesis that croaker and brown shrimp are associated with the edge of the hypoxic region, either due to preferential use of the edge or a herding effect associated with low oxygen avoidance, and evaluate 3 alternative models describing changes in abundance with increasing distance from the hypoxic edge. Given that croaker and brown shrimp are displaced both inshore and offshore of the hypoxic region (Craig et al. 2005), we also characterize the temperature and oxygen conditions occupied by organisms restricted to inshore habitats, those near the offshore edge of the hypoxic region, and those further offshore beyond the influence of hypoxia. We compare these conditions with those within the hypoxic region where neither species occurs to quantify the magnitude of potential shifts in temperature and oxygen distributions during years of severe hypoxia. We discuss these results in terms of the potential for hypoxia-induced habitat loss and shifts in spatial distribution to impact processes (i.e. growth and mortality) important for croaker and brown shrimp production.

\section{MATERIALS AND METHODS}

Bottom trawl surveys. An annual bottom trawl survey has been conducted during June-July in the northwestern Gulf of Mexico since 1982 and survey procedures were standardized in 1987 (Mississippi to
Texas-Mexico Border; Southeast Area Monitoring and Assessment Program, SEAMAP; Eldridge 1988). Surveys used a stratified random design based on depth and geographic location (Patella 1975). We confined analyses described below to the Louisiana continental shelf west of the Mississippi River where hypoxia typically occurs (Fig. 1, 89 to $94^{\circ}$ west longitude). Sampling in this region was typically conducted in a west to east direction over a 14 to 17 d period during July of each year. Surveys used a $12.8 \mathrm{~m}$ shrimp trawl with mud rollers and $2.4 \times 1 \mathrm{~m}$ wooden chained doors. The sampling objective was 1 day and 1 night tow perpendicular to the depth contours defining each stratum at a speed of 3 knots (10 to $60 \mathrm{~min}$ tow duration). No sampling was conducted inshore of $4 \mathrm{~m}$ due to depth limitations of the survey vessels. Bottom measurements of temperature, salinity, and dissolved oxygen were taken at the beginning location of each trawl with a conductivity, temperature, depth (CTD) probe. All croaker were counted and 20 per station measured (total length, TL, mm). All brown shrimp were sexed, counted, and 200 per station measured (TL, tip of rostrum to end of telson). Croaker were late juveniles (100 to 200 mm TL, Barger 1985) while brown shrimp were subadults (100 to $140 \mathrm{~mm}$ TL) prior to the fall-winter spawning period. Differences between spatial distributions of female and male brown shrimp were small and sex ratios were similar over years (Craig et al. 2005), so sexes were pooled. Catches were adjusted to a standard tow length of $2.8 \mathrm{~km}$ ( 1.5 nautical miles) prior to analysis. The number of stations sampled on the Louisiana shelf ranged from 112 to 125 per survey year. Additional details regarding the survey can be found in Craig et al. (2005) and the annual SEAMAP atlases (e.g. Rester et al. 2004). 
Analyses. Spatial distribution and relationship to abiotic factors: Hypoxia has occurred on the shelf in nearly every year since surveys began in the mid1980s (Rabalais et al. 2002, Craig et al. 2005). We pooled data from 5 years (1987 to 1989, 1998, and 2000) when hypoxia extended over relatively small areas $\left(\sim 0\right.$ to $\left.-7700 \mathrm{~km}^{2}\right)$ as the 'moderate hypoxia regime' and compared them to 5 years (1993 to 1997) of extensive hypoxia $\left(\sim 13400\right.$ to $\left.-17000 \mathrm{~km}^{2}\right)$ pooled as the 'severe hypoxia regime.' We used generalized additive models (GAM) to characterize the relationship between the spatial distribution of croaker and brown shrimp and environmental conditions on the Louisiana shelf. A GAM is a nonparametric partial regression technique that generates smoothed curves of the relationship between the response variable and each explanatory variable (Hastie \& Tibshirani 1990). We constructed separate models for each species with presence or absence as the response variable assuming a binomial error distribution. Explanatory variables included temporal (day of the survey, time of day), geographic (latitude, longitude, depth, distance from shore) and abiotic (bottom temperature, salinity, and dissolved oxygen) factors. Distance from shore was estimated as the minimum distance of each station from a continuous line overlaying the coastline and was measured in Arcview 3.2 using an equidistant conic projection (ESRI). We applied a cubic spline smoother with 4 degrees of freedom to each explanatory variable in the GAM analysis. We included year as a categorical (nonsmoothed) variable in models for each hypoxia regime to account for annual effects.

We used a backward stepwise selection procedure to compare alternative forms of each variable and eliminate those that did not contribute significantly to the model fit (app=roximate $F$-ratio statistic, $\mathrm{p}<0.05$; Venables \& Ripley 1999). We allowed each term to enter the model as a nonlinear smoothed effect, a linear (parametric) effect, or be excluded from the model. The only exception was 'year', which could only enter as a categorical variable or be excluded. We selected the model that minimized the Akaike Information Criterion (AIC), a statistic that considers the amount of variation explained by the variable penalized by the degrees of freedom used (Akaike 1973). We tested the significance of the linear and nonlinear (in the case of smoothed terms) components of each explanatory variable using an $F$-ratio statistic (Hastie \& Tibshirani 1990). All models were fit using the gam and stepgam procedures in Splus 2000 (Mathsoft).

Relationship to the hypoxic edge: We tested 3 alternative models describing the association of croaker and brown shrimp with the hypoxic edge. To quantify distance from the edge we estimated the $2.0 \mathrm{mg} \mathrm{l}^{-1}$ bot- tom dissolved oxygen contour using an equidistant conic projection as above and calculated the minimum distance of each station where croaker or brown shrimp were present from this contour line for the years comprising the severe hypoxia regime (1993 to 1997). These calculations were restricted to the offshore edge of the hypoxic region because limited sample sizes precluded a similar analysis of the inshore edge. Also, we only used stations in the 'middle' of the Louisiana shelf (90 to $93^{\circ}$ west longitude, Fig. 1) where interpolation indicated the hypoxic edge to be continuous and equivalent areas of offshore habitat were surveyed. Because environmental measurements were limited to the beginning location of the trawl, and trawl distances were relatively long (mean $2.8 \mathrm{~km}$ ) and perpendicular to depth contours, there is some uncertainty as to where croaker and brown shrimp occurred relative to the hypoxic edge. To address this, we created a $3 \mathrm{~km}$ buffer around the $2.0 \mathrm{mg} \mathrm{l}^{-1}$ oxygen contour and considered the distance to the edge of the hypoxic region to be zero for stations within this buffer. We then binned the remaining data into distance bins of $5 \mathrm{~km}$ from the offshore edge of the hypoxic region to $100 \mathrm{~km}$, the seaward limit of the survey. We adjusted croaker and brown shrimp catch rates for diel variation in catch efficiencies using species-specific correction factors (Craig 2001), and annual effects by multiplying each catch by the stratified mean catch rate in that particular year divided by the average stratified mean catch rate over the 5 severe hypoxia years (1993 to 1997). All catches were log-transformed prior to statistical analysis.

We used simple and partial Mantel regressions (Mantel 1967) to test the hypothesis that croaker and brown shrimp abundance was highest nearest the edge of the hypoxic region. Mantel regressions are a nonparametric partial regression technique based on dissimilarity (or distance) matrices that test whether stations that are similar in geographic location or environmental factors are also similar in croaker (or brown shrimp) abundance, after accounting for the effects of spatial autocorrelation within, as well as intercorrelation among (in the case of partial Mantel's), variables in the model. Variables included in the regressions were distance to the edge of the hypoxic region, temperature, dissolved oxygen, salinity, depth, and space (latitude, longitude). We computed dissimilarity matrices for each independent and dependent variable based on Euclidean distance. Statistical significance was assessed by randomly permuting the rows and columns of the dissimilarity matrices 10000 times, re-computing the Mantel test statistic for each permutation, and calculating the proportion of test statistics from the permuted matrices that were greater than that observed (Manly 1991). 
We considered linear, nonlinear, and threshold responses as 3 alternative models describing the association of croaker and brown shrimp with the hypoxic edge (Schick \& Urban 2000). The linear model was represented by absolute distance from the hypoxic edge, and is consistent with a monotonic decline in abundance with increasing distance. The nonlinear model was represented by the log of distance to the hypoxic edge. This model emphasizes shorter distances and de-emphasizes longer distances, and is consistent with an exponential decline in abundance with increasing distance from the edge. The threshold model represents a binary, rather than continuous, response with high abundance within some distance of the edge and low abundance beyond this distance. We used a classification and regression tree (CART, Breiman et al. 1984) with catch rate as the response variable and dissolved oxygen as the independent variable to determine an appropriate threshold distance for croaker and brown shrimp for this model.

Spatial and temporal variation in temperature and oxygen distributions: To characterize regional and annual variation in the average temperature and oxygen conditions that croaker and brown shrimp experience, we calculated catch-weighted means and standard deviations (SD) of temperature and oxygen as:

$$
\begin{gathered}
\text { Mean }=\frac{\sum\left(f_{i} x_{i}\right)}{\sum f_{i}} \\
\mathrm{SD}=\sqrt{\frac{\sum\left(f_{i} x_{i}^{2}\right)-\left(\sum f_{i}\right) \text { Mean }^{2}}{\left(\sum f_{i}\right)-1}}
\end{gathered}
$$

where $f_{i}$ is the number of croaker (or brown shrimp) per standard tow at Stn $i$ and $x_{i}$ is the temperature or oxygen measured at Stn $i$ (Murawski \& Finn 1988). To characterize shifts in temperature and oxygen distributions during severe hypoxia (1993 to 1997), we calculated these values for areas inshore, on the offshore hypoxic edge (defined by the CART and Mantel regressions above), and further offshore, presumably beyond the influence of hypoxia. To characterize annual variation in temperature and oxygen distributions we also calculated these values for the entire western Louisiana shelf ( 89 to $94^{\circ}$ west longitude) from 1987 to 2000 .
Table 1. Micropogonias undulatus. Results of generalized additive model (GAM) regressions on the occurrence (presence or absence) of croaker as a function of environmental variables during moderate $(1987-1989,1998,2000)$ and severe (1993-1997) hypoxia. Terms shown are those of the best fit models based on a smoothed fit. Where only results for the linear effect are reported, a linear term

\begin{tabular}{|lccccccc|}
\hline \multirow{2}{*}{ Parameter } & \multicolumn{3}{c}{ Linear effects } & \multicolumn{3}{c|}{ Nonlinear effects } \\
& df & $F$ & $\operatorname{Pr}(F)$ & df & $F$ & $\operatorname{Pr}(F)$ \\
\hline Moderate hypoxia: $\mathbf{R}^{2}=\mathbf{0 . 3 5}$ & & & & & & \\
Day & 1 & 1.50 & $0.22 \mathrm{~ns}$ & 2.9 & 2.34 & $0.074 \mathrm{~ns}$ \\
Time & 1 & 0.072 & $0.79 \mathrm{~ns}$ & 2.9 & 11.2 & $<0.001$ \\
Longitude & 1 & 8.70 & 0.003 & 3.0 & 3.89 & 0.010 \\
Depth & 1 & 24.2 & $<0.001$ & 2.9 & 4.40 & 0.005 \\
Temperature & 1 & 60.7 & $<0.001$ & & & \\
Oxygen & 1 & 2.80 & $0.09 \mathrm{~ns}$ & 2.9 & 5.95 & $<0.001$ \\
Distance from shore & 1 & 37.1 & $<0.001$ & 2.9 & 3.26 & 0.022 \\
Year & 4 & 5.55 & $<0.001$ & & & \\
Severe hypoxia: $\mathbf{R}^{2}=\mathbf{0 . 2 0}$ & & & & & & \\
Time & 1 & 2.74 & $0.099 \mathrm{~ns}$ & 3 & 7.42 & $<0.001$ \\
Latitude & 1 & 2.59 & $0.11 \mathrm{~ns}$ & 3 & 5.29 & 0.001 \\
Depth & 1 & 10.4 & 0.001 & & & \\
Salinity & 1 & 30.3 & $<0.001$ & 2.9 & 3.30 & 0.021 \\
Oxygen & 1 & 27.6 & $<0.001$ & 3.0 & 7.28 & $<0.001$ \\
Year & 4 & 6.24 & $<0.001$ & & & \\
\hline
\end{tabular}

\section{RESULTS}

\section{Relationship to abiotic factors during moderate and severe hypoxia}

The GAM regressions explained 35 and $20 \%$ of the variation in croaker occurrence (presence or absence) during moderate and severe hypoxia, respectively (Table 1). Dissolved oxygen had a significant nonlinear effect $(\mathrm{p}<0.001)$ on the distribution of croaker, with a sharp decline in frequency of occurrence at $<2 \mathrm{mg} \mathrm{l}^{-1}$ during both hypoxia periods (Figs. $2 \& 3$ ). The probability that croaker were present was relatively constant above $\sim 2 \mathrm{mg} \mathrm{l}^{-1}$, though there was some suggestion of an increase between 2 and $3 \mathrm{mg} \mathrm{l}^{-1}$ (moderate hypoxia) or 2 and $5 \mathrm{mg} \mathrm{l}^{-1}$ (severe hypoxia), possibly as a result of increased abundance near the hypoxic edge (see 'Relationship to the hypoxic edge' below). The effect of this avoidance behavior on the distribution of croaker with respect to temperature, however, differed between periods of moderate and severe hypoxia. During moderate hypoxia the probability that croaker were present increased with increasing temperature, and this effect was best represented by a linear term in the GAM regression (Table 1, Fig. 2), reflecting the tendency of croaker to occupy relatively warm $(\sim 26$ to $30^{\circ} \mathrm{C}$ ) nearshore waters. This nearshore distribution is 

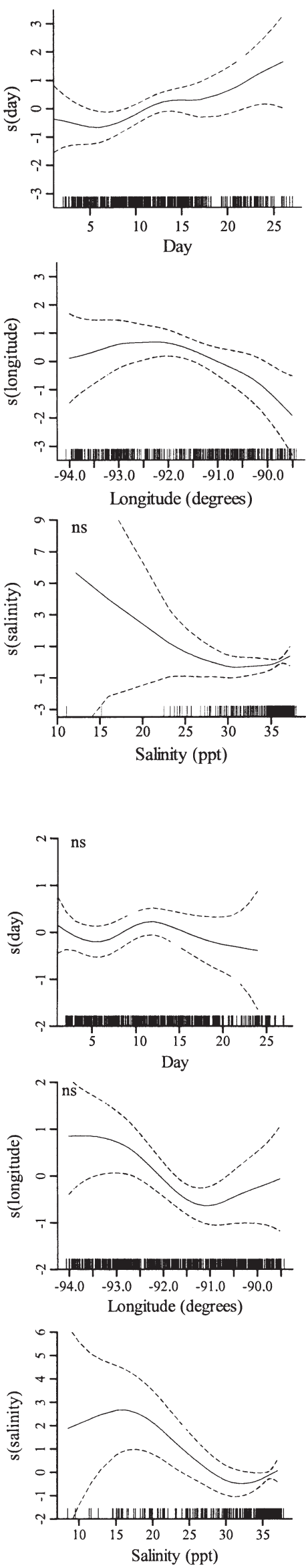
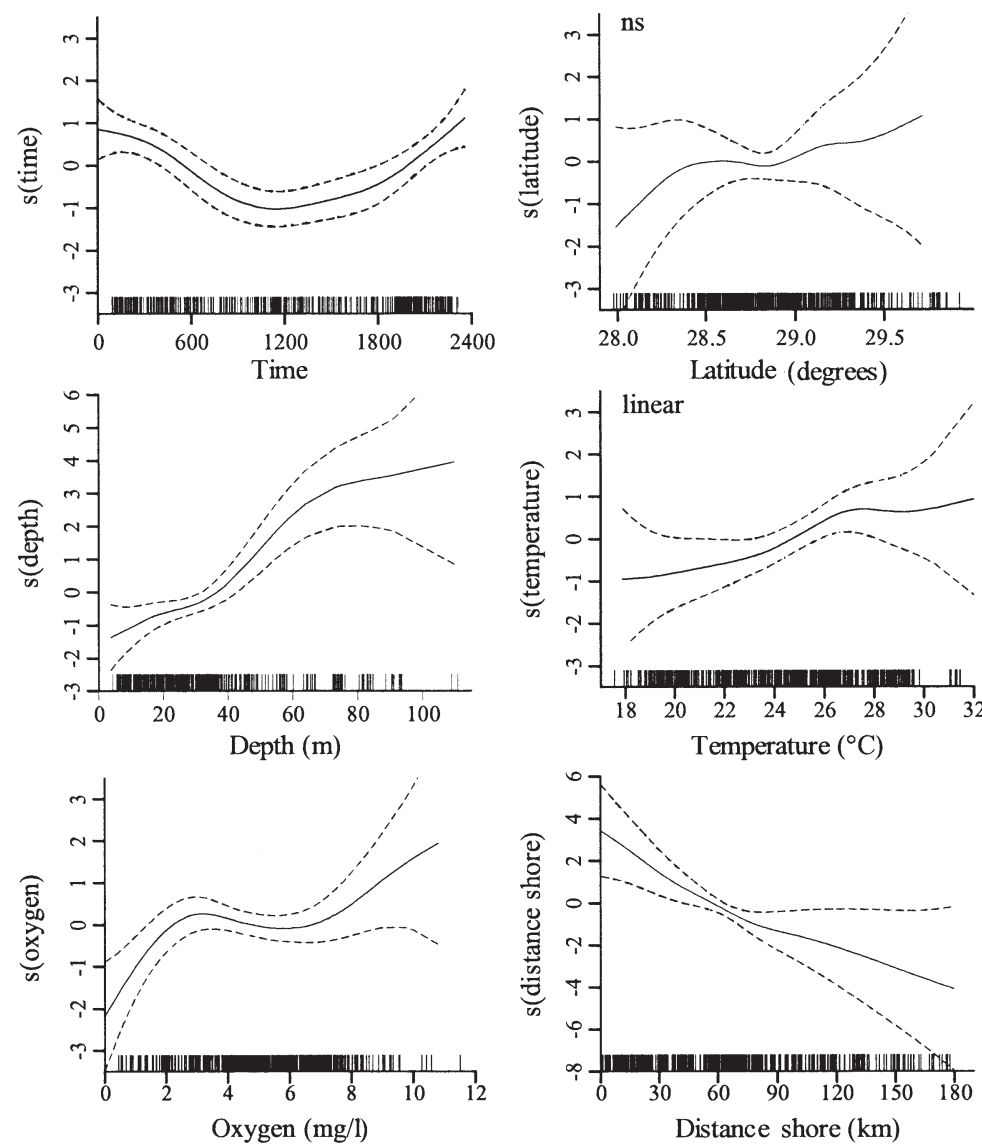

Fig. 2. Micropogonias undulatus. Cubic spline smoothed generalized additive model (GAM) plots of the distribution of croaker (presence, absence) during the moderate hypoxia regime relative to environmental variables. Variables that were not significant (ns) or entered only as a linear term are noted. Tick marks on $x$-axis indicate sampling intensity. Dashed curves are twice the standard error
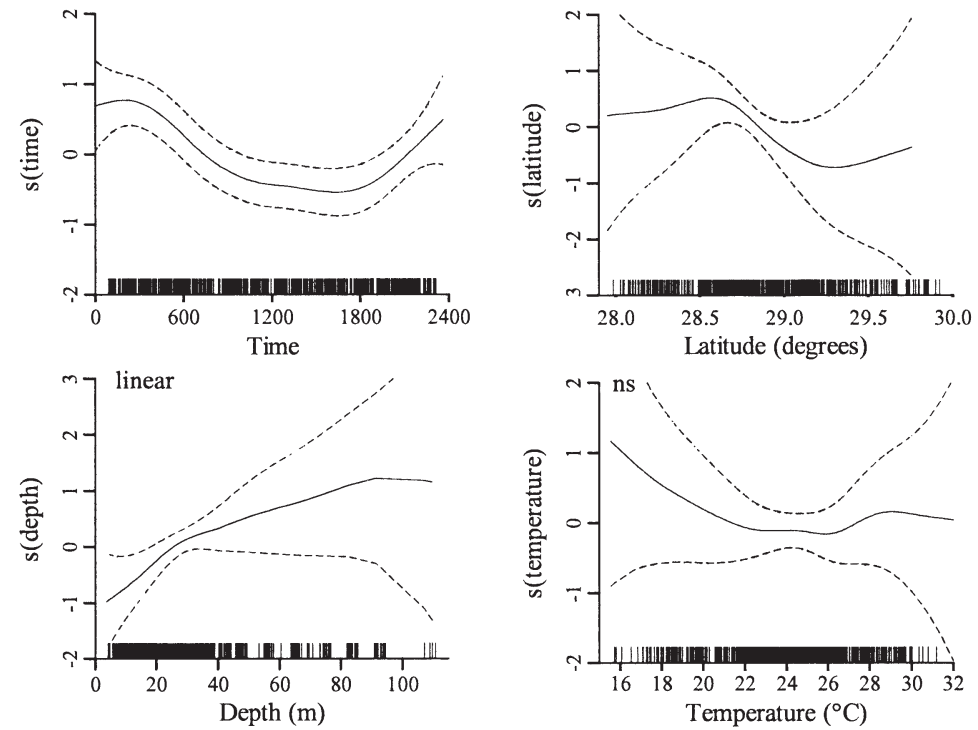

Fig. 3. Micropogonias undulatus. Cubic spline smoothed GAM plots of the distribution of croaker (presence, absence) during the severe hypoxia regime relative to environmental variables. Variables that were not significant (ns) or entered only as a linear term are noted. Tick marks on $x$-axis indicate sampling intensity. Dashed curves are twice the standard error 
Table 2. Farfantepenaeus aztecus. Results of GAM regressions on the occurrence (presence or absence) of brown shrimp as a function of environmental variables during moderate (1987-1989, 1998, 2000) and severe (1993-1997) hypoxia. Terms shown are those of the best fit models based on a backward stepwise selection procedure (see 'Materials and methods; Analyses' for details). Linear and nonlinear effects refer to the 2 components of the smoothed fit. Where only results for the linear effect are reported, a linear term entered the best fit model; otherwise, the smoothed term entered the model. Year could only enter as a categorical (nonsmoothed) variable. ns = nonsignificant

\begin{tabular}{|lcccccc|}
\hline \multirow{2}{*}{ Parameter } & \multicolumn{3}{c}{ Linear effects } & \multicolumn{3}{c|}{ Nonlinear effects } \\
& $\mathrm{df}$ & $F$ & $\operatorname{Pr}(F)$ & $\mathrm{df}$ & $F$ & $\operatorname{Pr}(F)$ \\
\hline Moderate hypoxia: & & & & & & \\
$\quad \mathbf{R}^{2}=\mathbf{0 . 3 6}$ & & & & & & \\
Day & 1 & 4.33 & 0.038 & 3.0 & 2.84 & 0.038 \\
Time & 1 & 0.418 & $0.52 \mathrm{~ns}$ & 2.8 & 13.5 & $<0.001$ \\
Latitude & 1 & 0.002 & $0.96 \mathrm{~ns}$ & 3.0 & 6.24 & $<0.001$ \\
Longitude & 1 & 1.93 & $0.17 \mathrm{~ns}$ & 2.8 & 7.96 & $<0.001$ \\
Depth & 1 & 18.4 & $<0.001$ & 2.8 & 10.6 & $<0.001$ \\
Salinity & 1 & 1.86 & $0.17 \mathrm{~ns}$ & 3.0 & 4.91 & 0.0023 \\
Oxygen & 1 & 18.2 & $<0.001$ & 3.0 & 14.0 & $<0.001$ \\
Distance from shore & 1 & 6.95 & $<0.001$ & 2.8 & 10.8 & $<0.001$ \\
Severe hypoxia: $\mathbf{R}^{2}=\mathbf{0 . 5 3}$ & & & & & & \\
Day & 1 & 4.08 & 0.044 & 3.0 & 4.9 & 0.002 \\
Time & 1 & 1.86 & $0.173 \mathrm{~ns}$ & 3.0 & 8.5 & $<0.001$ \\
Latitude & 1 & 119.0 & $<0.001$ & 3.0 & 12.2 & $<0.001$ \\
Longitude & 1 & 10.6 & 0.0012 & 2.8 & 3.96 & 0.010 \\
Depth & 1 & 47.5 & $<0.001$ & 3.0 & 34.6 & $<0.001$ \\
Temperature & 1 & 22.0 & $<0.001$ & 3.0 & 2.24 & 0.082 \\
Salinity & 1 & 45.1 & $<0.001$ & 3.0 & 10.6 & $<0.001$ \\
Oxygen & 1 & 82.2 & $<0.001$ & 3.0 & 16.0 & $<0.001$ \\
Distance from shore & 4 & 10.7 & $<0.001$ & & & \\
\hline
\end{tabular}

of oxygen was similar to that of croaker, with a sharp decline in occurrence below $\sim 2 \mathrm{mg} \mathrm{l}^{-1}$, and nearly constant occurrence above this level during moderate hypoxia (Fig. 4) or peaked occurrence at intermediate oxygen levels (i.e. $\sim 2$ to $5 \mathrm{mg} \mathrm{l}^{-1}$ ) during severe hypoxia (Fig. 5). Avoidance of low oxygen water was also evident in more peaked brown shrimp distributions with respect to latitude and depth during severe (Fig. 5) compared to moderate (Fig. 4) hypoxia. Low oxygen avoidance and associated habitat loss altered the temperature distribution of brown shrimp as well, but the effect was opposite to that for croaker. When hypoxia was not extensive, brown shrimp occurred across nearly the full range of available temperatures with the exception of the warmest inshore waters $\left(28\right.$ to $32^{\circ} \mathrm{C}$ ), and a small peak occurred at intermediate temperatures $\left(\sim 24\right.$ to $\left.26^{\circ} \mathrm{C}\right)$ (Fig. 4). In contrast, during severe hypoxia brown shrimp were most prevalent in the warmest inshore waters ( 28 to $\left.31^{\circ} \mathrm{C}\right)$ and occurrence declined with decreasing temperature (Fig. 5). In contrast to croaker, temalso reflected in GAM plots showing a higher probability that croaker were present closer to shore (Fig. 2). Distance to shore and water depth are not necessarily correlated across the Louisiana shelf, however, as the shelf broadens toward the west and has a sharper slope with depth in the east, so that relatively deep water can occur both short and long distances from shore. This likely accounts for the different relationships with depth and distance to shore (Figs. 1 \& 2). In contrast, during severe hypoxia temperature did not enter the best fit model for croaker although there was some suggestion of increases in frequency of occurrence at both high $\left(28\right.$ to $\left.30^{\circ} \mathrm{C}\right)$ and low $\left(<22^{\circ} \mathrm{C}\right)$ temperatures (Fig. 3). This temperature distribution during severe hypoxia is consistent with displacement of some croaker offshore of the hypoxic region to lower temperatures while some fish are displaced to, or remain in, relatively warm inshore waters. The offshore shift in the distribution of croaker during severe hypoxia is also reflected in GAM plots showing a peak in frequency of occurrence at lower latitudes compared to moderate hypoxia (Figs. 2 \& 3).

The GAM regressions explained 36 and $53 \%$ of the variation in brown shrimp occurrence during moderate and severe hypoxia, respectively (Table 2). The effect perature was not significant $(p>0.05)$ in models of brown shrimp during moderate hypoxia but was significant during severe hypoxia (compare Tables 1 \& 2).

The different patterns in the temperatures occupied by croaker and brown shrimp during severe and moderate hypoxia suggest an interaction effect between these factors on the distribution of both species. To further evaluate this possibility, we fit a generalized linear model with terms for hypoxia regime, year ature, and temperature $\times$ hypoxia regime interaction. The interaction between temperature and hypoxia regime was highly significant for croaker and explained $\sim 39 \%$ of the model $\mathrm{R}^{2}$ (Table 3 ). For brown shrimp this interaction was also significant but was less important, explaining only $5.3 \%$ of the model $\mathrm{R}^{2}$.

\section{Relationship to the hypoxic edge}

Densities of croaker and brown shrimp were high on the offshore hypoxic edge and declined rapidly with increasing distance from the edge (Fig. 6). The threshold distance from the CART model that maximized the difference in catch rates with distance from the edge nested within hypoxia regime (random effect), temper- 

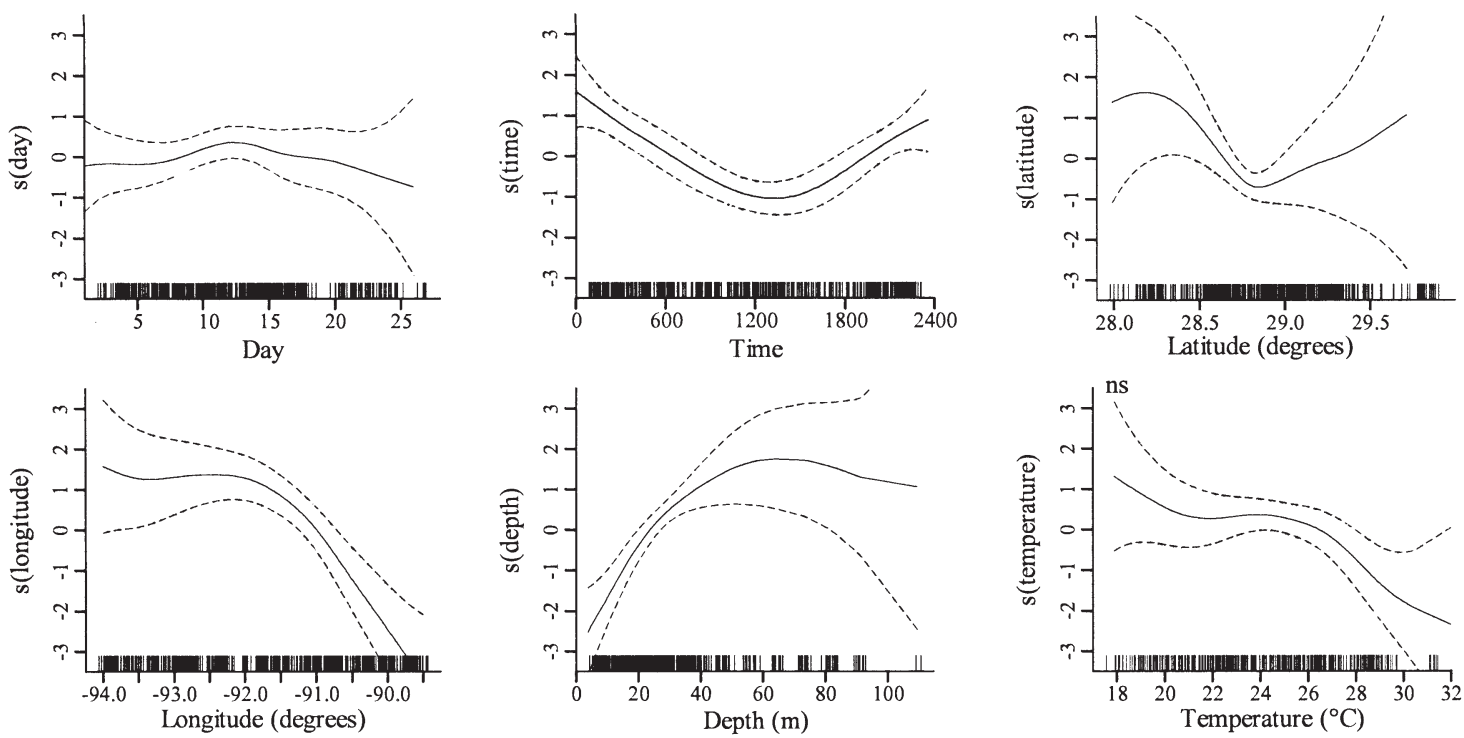

Fig. 4. Farfantepenaeus aztecus. Cubic spline smoothed GAM plots of the distribution of brown shrimp (presence, absence) during the moderate hypoxia
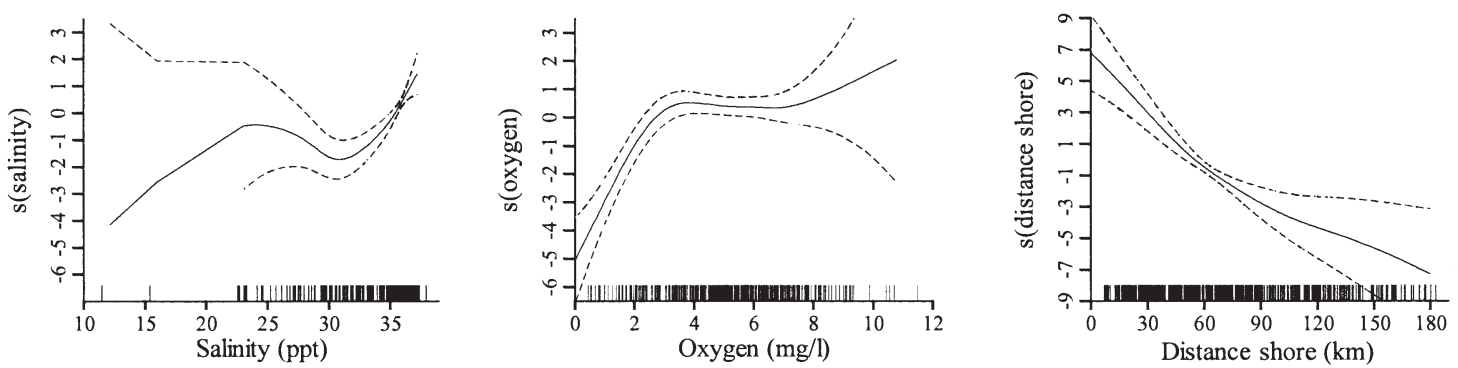
regime relative to environmental variables. Variables that were not significant (ns) or entered only as a linear term are noted. Tick marks on $x$-axis indicate sampling intensity. Dashed curves are twice the standard error
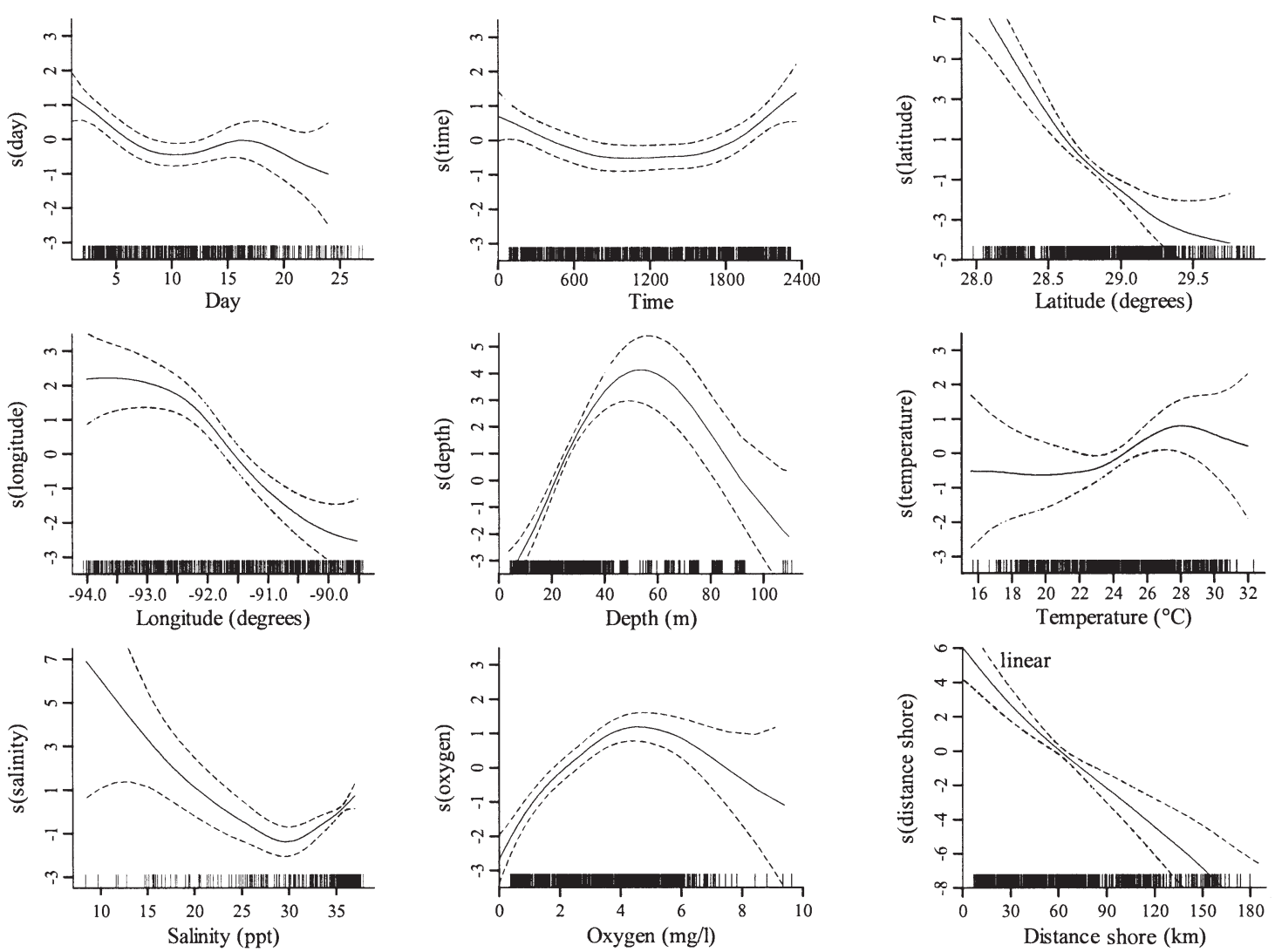

Fig. 5. Farfantepenaeus aztecus. Cubic spline smoothed GAM plots of the distribution of brown shrimp (presence, absence) during the severe hypoxia regime relative to environmental variables. Tick marks on $x$-axis indicate sampling intensity. Dashed curves are twice the standard error 
Table 3. Micropogonias undulatus and Farfantepenaeus aztecus. Results of generalized linear models for croaker and brown shrimp testing for an interaction between temperature and hypoxia regime (moderate, severe). Values are the percentage of the model $\mathrm{R}^{2}$ accounted for by each term. $\mathrm{p}$-values given in parentheses. Sample size $=1076$

\begin{tabular}{|lcccc|}
\hline Presence/absence & Hypoxia regime & Year in hypoxia regime & Temperature & Hypoxia regime $\times$ Temperature \\
\hline Croaker & 5.7 & 40.0 & 15.2 & 39.0 \\
Shrimp & $(0.013)$ & $(<0.0001)$ & $(<0.0001)$ & $(<0.0001)$ \\
& 14.6 & 16.4 & 63.7 & 5.3 \\
\end{tabular}

was $5 \mathrm{~km}$ for croaker and $20 \mathrm{~km}$ for brown shrimp. Sixty-eight percent of croaker and $62 \%$ of brown shrimp offshore of the hypoxic region were within $5 \mathrm{~km}$ of the edge. Eighty-two percent of brown shrimp were within the $20 \mathrm{~km}$ threshold identified by the CART model.

In Mantel regressions, there was no spatial autocorrelation in croaker catch rates while environmental variables were generally spatially autocorrelated (Table 4). Even so, simple (Column 1) and partial (Column 4) regressions gave similar results, with only dissolved oxygen and distance to the hypoxic edge significant. Both the nonlinear and threshold models of distance to the edge were significant while the
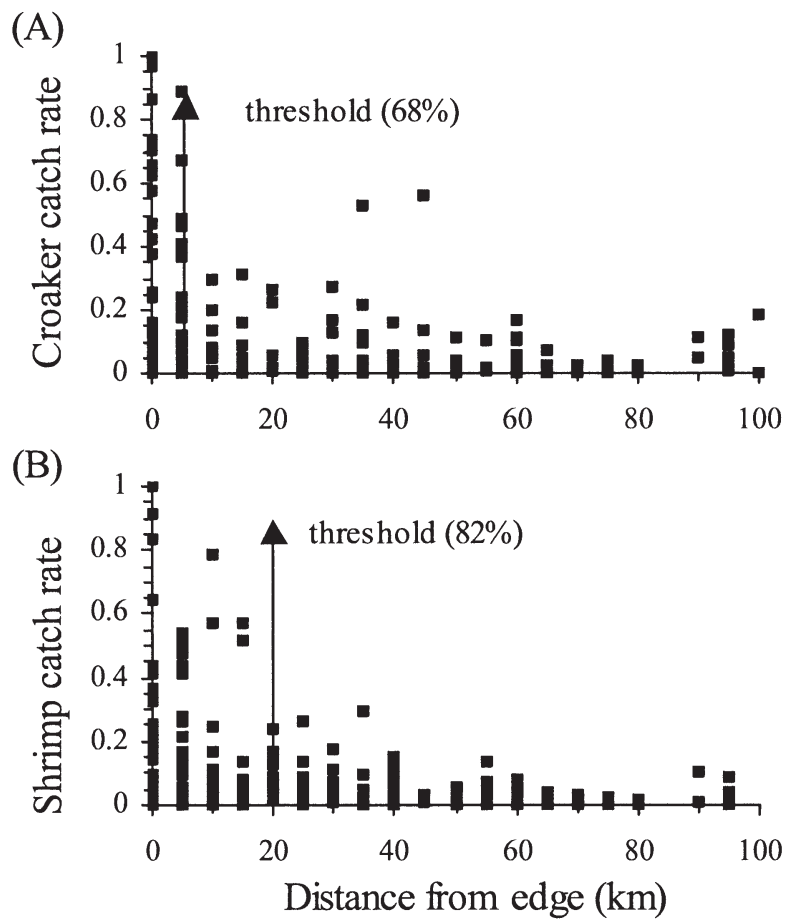

Fig. 6. Micropogonias undulatus and Farfantepenaeus aztecus. Relationship between (A) croaker and (B) brown shrimp scaled catch rates and distance to the offshore edge of the hypoxic region $(5 \mathrm{~km}$ distance bins). Arrows denote thresholds of distance from the edge based on classification and regression tree (CART) models (see 'Materials and methods; Analyses') linear model was not. The nonlinear model, however, explained 26.8 and $41.4 \%$ more of the variation in croaker catch rates than the threshold model in simple and partial regressions, respectively.

In contrast to croaker, depth, temperature and distance to the hypoxic edge were all significant in simple Mantel regressions for brown shrimp while oxygen was not (Table 5, Column 1). All 3 models of distance to the edge were significant, though the nonlinear model explained $\sim 40 \%$ more of the variation than the linear model and $\sim 58 \%$ more than the threshold model in both simple and partial regressions accounting for spatial autocorrelation (Table 5, Columns 1 and 3). For partial regressions accounting for both spatial auto-

Table 4. Micropogonias undulatus. Mantel $\mathrm{r}$ coefficients and p-values (ns = nonsignificant) for simple and partial Mantel regressions on croaker catch rates offshore of the hypoxic region, 1993-1997. Column 1: simple regression of croaker on each variable (env = environmental). Column 2: simple regression of each variable on space. Column 3: partial regression of croaker on each variable controlling for spatial autocorrelation. Column 4: partial regression of croaker on each variable controlling for spatial autocorrelation and intercorrelation among variables. p-values are 1-tailed and are based on 10000 permutations of the distance matrices. The range of values (Column 4) are for separate regressions with each of the 3 models of distance to the hypoxic edge

\begin{tabular}{|c|c|c|c|c|}
\hline & $\begin{array}{c}\text { Simple } \\
\text { (env) }\end{array}$ & $\begin{array}{l}\text { Simple } \\
\text { (space) }\end{array}$ & $\begin{array}{l}\text { Partial } \\
\text { (space) }\end{array}$ & $\begin{array}{c}\text { Partial } \\
\text { (space/env) }\end{array}$ \\
\hline Croaker & & ns & & ns \\
\hline Depth & ns & $\mathrm{ns}$ & ns & ns \\
\hline Salinity & ns & $\begin{array}{c}0.149 \\
(<0.001)\end{array}$ & ns & ns \\
\hline Temperature & $\mathrm{ns}$ & $\begin{array}{c}0.079 \\
(<0.001)\end{array}$ & ns & ns \\
\hline Oxygen & $\begin{array}{c}0.101 \\
(0.002)\end{array}$ & $\begin{array}{c}0.058 \\
(<0.001)\end{array}$ & $\begin{array}{c}0.101 \\
(<0.001)\end{array}$ & $\begin{array}{r}0.064-0.100 \\
(0.003-0.025)\end{array}$ \\
\hline $\begin{array}{l}\text { Distance edge } \\
\text { (linear) }\end{array}$ & $\mathrm{ns}$ & $\begin{array}{c}0.358 \\
(<0.001)\end{array}$ & ns & ns \\
\hline $\begin{array}{l}\text { Distance edge } \\
\text { (nonlinear) }\end{array}$ & $\begin{array}{c}0.104 \\
(0.001)\end{array}$ & $\begin{array}{c}0.299 \\
(<0.001)\end{array}$ & $\begin{array}{c}0.110 \\
(<0.001)\end{array}$ & $\begin{array}{c}0.082 \\
(0.003)\end{array}$ \\
\hline $\begin{array}{l}\text { Distance edge } \\
\text { (threshold) }\end{array}$ & $\begin{array}{c}0.082 \\
(0.005)\end{array}$ & $\begin{array}{c}0.105 \\
(<0.001)\end{array}$ & $\begin{array}{c}0.082 \\
(0.004)\end{array}$ & $\begin{array}{c}0.058 \\
(0.022)\end{array}$ \\
\hline
\end{tabular}


Table 5. Farfantepenaeus aztecus. Mantel r coefficients and p-values (ns = nonsignificant) for results of simple and partial Mantel regressions on brown shrimp catch rates offshore of the hypoxic region, 1993-1997. Column 1: simple regression of brown shrimp on each variable (env = environmental). Column 2: simple regression of each variable on space. Column 3: partial regression of brown shrimp on each variable controlling for spatial autocorrelation. Column 4: partial regression of brown shrimp on each variable controlling for spatial autocorrelation and intercorrelation among variables. p-values are 1-tailed and are based on 10000 permutations of the distance matrices. The range of values (Column 4) are for separate regressions with each of the 3 models of distance to the hypoxic edge

\begin{tabular}{|c|c|c|c|c|}
\hline & $\begin{array}{l}\text { Simple } \\
\text { (env) }\end{array}$ & $\begin{array}{l}\text { Simple } \\
\text { (space) }\end{array}$ & $\begin{array}{l}\text { Partial } \\
\text { (space) }\end{array}$ & $\begin{array}{c}\text { Partial } \\
\text { (space/env) }\end{array}$ \\
\hline Shrimp & & $\begin{array}{c}0.067 \\
(0.004)\end{array}$ & & $\begin{array}{c}0.038-0.051 \\
(0.002-0.029)\end{array}$ \\
\hline Depth & $\begin{array}{c}0.147 \\
(<0.001)\end{array}$ & $\begin{array}{c}0.119 \\
(<0.001)\end{array}$ & $\begin{array}{c}0.141 \\
(<0.001)\end{array}$ & $\begin{array}{l}0.0790 .099 \\
(0.001)\end{array}$ \\
\hline Salinity & ns & $\begin{array}{c}0.138 \\
(<0.001)\end{array}$ & ns & ns \\
\hline Temperature & $\begin{array}{c}0.103 \\
(<0.001)\end{array}$ & $\begin{array}{c}0.071 \\
(<0.001)\end{array}$ & $\begin{array}{c}0.098 \\
(0.001)\end{array}$ & ns \\
\hline Oxygen & ns & $\begin{array}{c}0.177 \\
(<0.001)\end{array}$ & ns & ns \\
\hline $\begin{array}{l}\text { Distance edge } \\
\text { (linear) }\end{array}$ & $\begin{array}{c}0.090 \\
(0.001)\end{array}$ & $\begin{array}{c}0.281 \\
(<0.001)\end{array}$ & $\begin{array}{c}0.074 \\
(0.008)\end{array}$ & ns \\
\hline $\begin{array}{l}\text { Distance edge } \\
\text { (nonlinear) }\end{array}$ & $\begin{array}{c}0.126 \\
(0.001)\end{array}$ & $\begin{array}{c}0.227 \\
(<0.001)\end{array}$ & $\begin{array}{c}0.114 \\
(<0.001)\end{array}$ & $\begin{array}{c}0.057 \\
(0.006)\end{array}$ \\
\hline $\begin{array}{l}\text { Distance edge } \\
\text { (threshold) }\end{array}$ & $\begin{array}{c}0.080 \\
(0.001)\end{array}$ & $\begin{array}{c}0.230 \\
(<0.001)\end{array}$ & $\begin{array}{c}0.066 \\
(0.001)\end{array}$ & ns \\
\hline
\end{tabular}

correlation and intercorrelations among variables, only depth and the nonlinear model of distance to the hypoxic edge were significant (Table 5, Column 4). These results indicate that brown shrimp are strongly associated with the offshore hypoxic edge as well, but at greater distances than croaker (within $\sim 20 \mathrm{~km}$ ) given their typically broader spatial distribution. In contrast to croaker, brown shrimp catch rates varied with depth and were still spatially autocorrelated even after accounting for environmental variables (Table 5, Columns 2 and 4), indicating other unmeasured factors are important in brown shrimp distribution.

\section{Spatial and temporal variation in temperature and oxygen distributions}

On average, croaker and brown shrimp occupied a 7 to $9^{\circ} \mathrm{C}$ temperature range during severe hypoxia, decreasing from $\sim 29-31^{\circ} \mathrm{C}$ inshore to $\sim 21-23^{\circ} \mathrm{C}$ offshore (Fig. 7A,B). Mean temperatures occupied on the offshore edge of the hypoxic region $\left(\sim 23\right.$ to $\left.24^{\circ} \mathrm{C}\right)$, as well as those within the hypoxic region that were presum- ably unavailable $\left(\sim 25\right.$ to $\left.27^{\circ} \mathrm{C}\right)$, were intermediate to these extremes. The minimum shift in temperature of croaker displaced inshore of the hypoxia region (mean inshore temperature - mean hypoxic temperature) was approximately $+3.6^{\circ} \mathrm{C}$ and those displaced offshore (mean offshore edge - mean hypoxic) was $-1.9^{\circ} \mathrm{C}$, while that for brown shrimp was $+4.0^{\circ} \mathrm{C}$ inshore and $-2.4^{\circ} \mathrm{C}$ offshore (averaged from 1993 to 1997). The difference in temperatures occupied inshore and on the offshore edge of the hypoxic region were $\sim 5$ to $6^{\circ} \mathrm{C}$ for croaker $(<5 \mathrm{~km})$ and $\sim 4$ to $9^{\circ} \mathrm{C}$ for brown shrimp $(<20 \mathrm{~km})$.

These shifts in spatial distribution and associated temperature were reflected in changes in the mean annual temperatures occupied by croaker and brown shrimp on the western Louisiana shelf (Fig. 7A,B). Mean temperatures occupied by croaker declined by $\sim 1$ to $2^{\circ} \mathrm{C}$ from $\sim 27$ to $28^{\circ} \mathrm{C}$ during the mid-1980s and early 1990 s to $\sim 26^{\circ} \mathrm{C}$ during the mid- to late 1990 s (Fig. 7A). In contrast, mean temperatures occupied by brown shrimp increased by $\sim 1^{\circ} \mathrm{C}$ from $\sim 25$ to $\sim 26^{\circ} \mathrm{C}$ over the same period (Fig. $7 \mathrm{~B}$ ). The mean annual temperatures occupied by croaker were positively correlated with mean bottom oxygen concentrations ( $\mathrm{r}=$ 0.85, $\mathrm{p}<0.001, \mathrm{n}=13$ ) and negatively correlated with the area of hypoxia ( $\mathrm{r}=-0.83, \mathrm{p}<0.001, \mathrm{n}=13$ ), reflecting the lower occupied temperatures that result from offshore shifts in distribution due to hypoxia. The opposite occurred for brown shrimp (mean oxygen: $\mathrm{r}=-0.66, \mathrm{p}=0.01$; area hypoxia: $\mathrm{r}=0.76, \mathrm{p}=0.003$; $\mathrm{n}=13$ ), reflecting high abundance in warm waters inshore of extensive hypoxic regions.

Despite avoidance of the lowest oxygen waters on the shelf and associated shifts in distribution both inshore and offshore, oxygen levels occupied by croaker and brown shrimp varied spatially in relation to the hypoxic region (Fig. 7C,D). The highest oxygen levels occupied by both species ( 5 to $6 \mathrm{mg} \mathrm{l}^{-1}$, 90\% saturation) were inshore of the hypoxic region, likely due to wind mixing and tidal influences that inhibit stratification and low oxygen in shallow water. Well offshore of the hypoxic region beyond the influence of hypoxia (>5 and >20 km for croaker and brown shrimp, respectively), mean oxygen levels occupied were also relatively high $\left(\sim 3\right.$ to $4 \mathrm{mg} \mathrm{l}^{-1}$ for croaker, $\sim 4$ to $5 \mathrm{mg} \mathrm{l}^{-1}$ for brown shrimp; $\sim 65$ to $85 \%$ saturation). The lowest oxygen levels occupied by both species were on the offshore edge of the hypoxic region and averaged $\sim 2.1 \mathrm{mg} \mathrm{l}^{-1}$ ( 45\% saturation) for croaker and $\sim 2.8 \mathrm{mg} \mathrm{l}^{-1}$ ( $60 \%$ saturation) for brown shrimp over the 5 years of severe hypoxia (1993 to 1997). Mean oxygen levels within the hypoxic region during these years where neither species occurred ranged from 0.5 to $1.4 \mathrm{mg} \mathrm{l}^{-1}$ on average (11 to $30 \%$ saturation). The mean oxygen levels occupied by croaker were posi- 

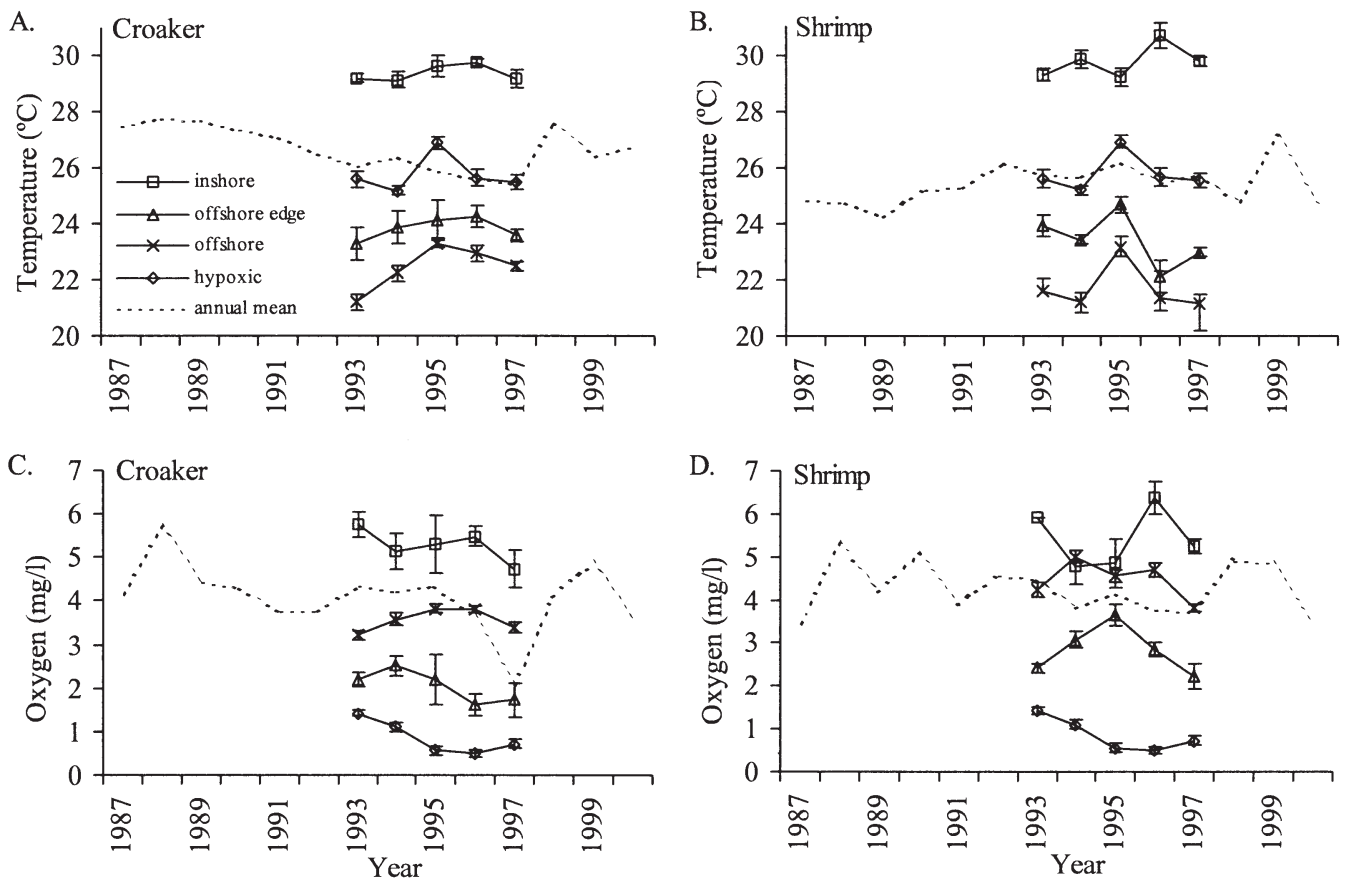

Fig. 7. Micropogonias undulatus and Farfantepenaeus aztecus. Catch weighted mean temperature and oxygen levels occupied by croaker and brown shrimp (1993-1997) inshore of the hypoxic region, on the offshore edge $(<5$ and $20 \mathrm{~km}$ for croaker and brown shrimp, respectively), further offshore beyond the edge ( $>5$ and $20 \mathrm{~km})$, as well as mean values within the hypoxic region $\left(<2.0 \mathrm{mg} \mathrm{l}^{-1}\right)$ that were avoided or unavailable. Bars are standard errors. Dashed lines are the catch weighted mean temperature or oxygen levels occupied by croaker and brown shrimp over the entire shelf, 1987-2000

tively correlated with mean bottom oxygen concentrations on the shelf $(\mathrm{r}=0.77, \mathrm{p}<0.003, \mathrm{n}=13)$ and negatively correlated with the area of hypoxia $(\mathrm{r}=-0.53$, $\mathrm{p}=0.06, \mathrm{n}=13$ ), reflecting the lower oxygen levels occupied when hypoxia was severe. Similar patterns were evident for brown shrimp though correlations were weaker and not significant (mean oxygen: $\mathrm{r}=$ $0.40, \mathrm{p}=0.17$; area hypoxia: $\mathrm{r}=-0.25, \mathrm{p}=0.42 ; \mathrm{n}=13$ ).

As a result of the disjunct distribution of both species inshore and offshore of the hypoxic region, variation in temperature and oxygen conditions experienced by croaker and brown shrimp was greater in years of severe hypoxia (Fig. 8). The coefficient of variation of the annual temperatures occupied by croaker nearly doubled and those occupied by brown shrimp increased by $\sim 50 \%$ from the 1980 s and early 1990s, when hypoxia was moderate, to the mid-late 1990s, when hypoxia was severe (Fig. 8A). Temperature variation was positively correlated with the area of hypoxia (croaker: $\mathrm{r}=0.62, \mathrm{p}=0.02$; shrimp: $\mathrm{r}=0.51, \mathrm{p}=$ $0.07 ; \mathrm{n}=13$ ) and negatively correlated with mean oxygen levels on the shelf (croaker: $r=-0.65, p=0.02$; shrimp: $\mathrm{r}=-0.34, \mathrm{p}=0.26 ; \mathrm{n}=13$ ), though correlations were stronger for croaker than for brown shrimp. Similarly, variation in annual oxygen levels occupied by croaker increased as mean oxygen levels on the shelf declined and the area of hypoxia increased (Fig. 8B;

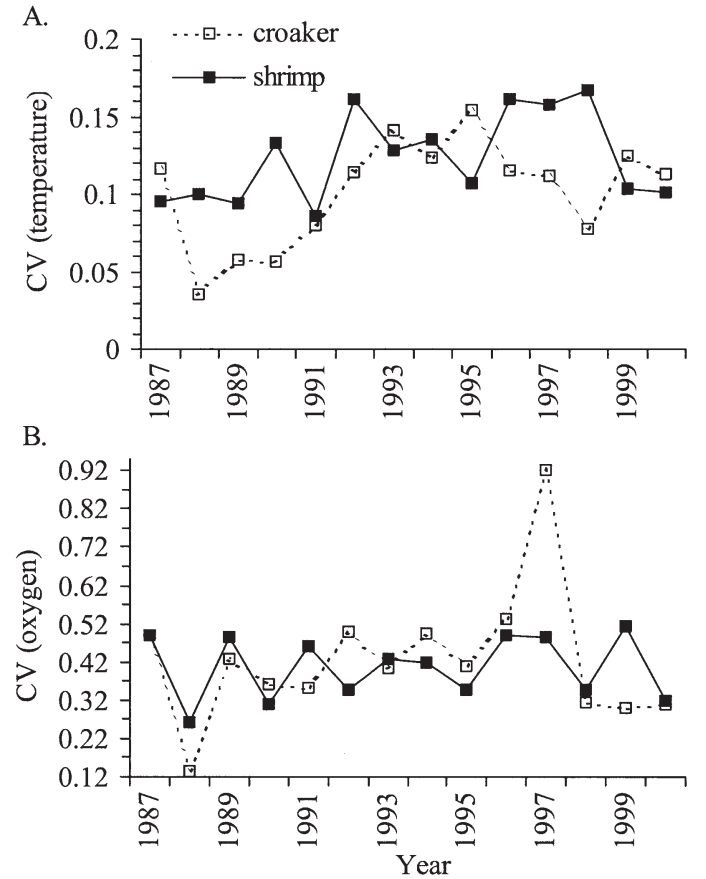

Fig. 8. Micropogonias undulatus and Farfantepenaeus aztecus. Annual coefficients of variation (CV) in (A) temperature and (B) oxygen levels occupied by croaker and brown shrimp on the Louisiana shelf, 1987-2000. The high CV for croaker in 1997 was the result of a few extremely high catch rates in the vicinity of the hypoxic edge 
mean oxygen: $\mathrm{r}=-0.65, \mathrm{p}=0.02$; area hypoxia: $\mathrm{r}=$ $0.62, \mathrm{p}=0.02 ; \mathrm{n}=13$ ), reflecting the large difference in available oxygen conditions inshore and on the offshore edge of the hypoxic region. Similar patterns were evident for brown shrimp though correlations were not significant (Fig. 8B; mean oxygen: $r=-0.34$, $\mathrm{p}=0.26$; area hypoxia: $\mathrm{r}=0.49, \mathrm{p}=0.09 ; \mathrm{n}=13$ ).

\section{DISCUSSION}

We have previously shown that habitat loss due to hypoxia can be extensive for demersal species on the western Louisiana shelf, approaching $\sim 50$ and $~ 25 \%$ for Atlantic croaker and brown shrimp, respectively (Craig et al. 2001, 2005). While avoidance of low oxygen has been documented in the laboratory (Wannamaker \& Rice 2000) and the field (Eby \& Crowder 2002), studies have not typically examined the consequences of avoidance behavior for the abiotic conditions that organisms experience beyond the margins of hypoxic regions. In systems where hypoxic regions are particularly large, such as the northwestern Gulf of Mexico, or gradients in abiotic conditions are strong, avoidance of low oxygen may result in shifts in the abiotic conditions that organisms experience. Here we have shown that one consequence of hypoxia is a shift in the temperature and dissolved oxygen conditions that croaker and brown shrimp experience when displaced from hypoxic regions to other habitats. Because temperature and dissolved oxygen are 2 abiotic factors that influence the metabolic scope of organisms, one potential effect of hypoxia-induced shifts in spatial distribution is a decrease in the energy available for growth and other fitness-related activities that result from occupying suboptimal abiotic conditions. Similar vertical avoidance of bottom water hypoxia has been shown to force pelagic fishes into warmer, suboptimal surface waters, decreasing fish growth potential (i.e. Coutant 1985, Brandt \& Mason 2003). Habitat loss and associated high densities of croaker and brown shrimp near hypoxic edges also suggests the potential for a variety of effects on biotic interactions (foraging, competition, predation) that may interact with changes in abiotic conditions to impact growth and mortality. In particular low oxygen avoidance can have large and often unexpected effects on foraging success (Rahel \& Nutzman 1994) and predation mortality (Breitburg et al. 1999), though these are not well known for the Gulf of Mexico. For mobile species, it is the integration of these indirect effects on growth and mortality processes resulting from avoidance behavior and shifts in spatial distribution that will determine the population level consequences of hypoxia.

\section{Shifts in temperature distribution in relation to hypoxia}

Metabolic scope is typically maximized at temperatures a few degrees below lethal temperatures and generally decreases more rapidly above than below this optimum (Brett 1979, Jobling 1994). Croaker, which typically occupy warm, inshore waters (Darnell et al. 1983, Craig 2001) occurred inshore $\left(\sim 29\right.$ to $\left.31^{\circ} \mathrm{C}\right)$ but were also displaced to cooler offshore waters ( 23 to $25^{\circ} \mathrm{C}$ ) when hypoxia was severe. The relationship between metabolic scope of croaker and temperature is unknown. Laboratory studies with juvenile croaker and other sciaenid fishes suggest relatively high optimal temperatures for growth $\left(27\right.$ to $31^{\circ} \mathrm{C}$; Pendleton 1973, Jones \& Strawn 1986, Wang et al. 1997). Indirect estimates of optimal temperatures based on critical thermal maxima, upper avoidance levels, and final preferendum range from 28 to $31^{\circ} \mathrm{C}$ for several sciaenids (Coutant 1977, Hodson et al. 1981, Jobling 1981, Ward 1993). The relatively low temperatures that croaker experience on the offshore edge of the hypoxic region $\left(\sim 23\right.$ to $\left.24^{\circ} \mathrm{C}\right)$ in conjunction with their typical nearshore distribution in the warmest available waters (Darnell et al. 1983, Craig et al. 2005) suggest low temperature may reduce energy available for growth and other activities for croaker displaced offshore due to hypoxia.

While brown shrimp are more broadly distributed than croaker and, hence, occupy a broader range of temperatures $\left(\sim 21\right.$ to $\left.29^{\circ} \mathrm{C}\right)$, the highest densities historically occurred in regions now subject to hypoxia (Darnell et al. 1983, Craig et al. 2005). The difference in temperatures occupied by brown shrimp inshore $\left(\sim 29\right.$ to $\left.31^{\circ} \mathrm{C}\right)$ versus offshore $\left(\sim 22\right.$ to $\left.25^{\circ} \mathrm{C}\right)$ of the hypoxic region encompasses those where growth of other subadult penaeids (100 to $140 \mathrm{~mm}$ TL) is sensitive to temperature $\left(\sim 23\right.$ to $27^{\circ} \mathrm{C}$; Villarreal \& Ocampo 1993, Wyban et al. 1995). Optimal temperatures for brown shrimp may be lower than for croaker, with estimates for congeneric species ranging from $\sim 26$ to $28^{\circ} \mathrm{C}$ based on laboratory studies (Wyban et al. 1995, Coman et al. 2002), temperature tolerances and general relationships with temperature optima (Zein-Eldin \& Griffith 1969, Jobling 1981), and field studies (LópezMartínez et al. 2003). In addition, at temperatures $>30^{\circ} \mathrm{C}$ several studies report thermal stress (Bishop et al. 1980, Villarreal \& Ocampo 1993) or little growth (Wyban et al. 1995, Ponce-Palafox et al. 1997, Coman et al. 2002). This suggests that brown shrimp restricted to warm inshore waters during severe hypoxia may experience increased metabolic costs and decreases in metabolic scope, particularly during warm years (e.g. Fig. $7 \mathrm{~B}, 1996$, mean temperature $=31^{\circ} \mathrm{C}$ ). Similarly, the above studies generally report declines in growth 
at temperatures $<24$ to $25^{\circ} \mathrm{C}$, suggesting brown shrimp near the offshore hypoxic edge may experience decreases in metabolic scope as well.

Whether hypoxia-induced shifts in temperature distribution result in realized declines in croaker and brown shrimp growth is unknown. Temperature effects on growth energetics are complicated because temperature impacts both consumption and metabolic costs in different ways (Railsback \& Rose 1999), and temperature optima scale with ration (Elliott 1975) as well as body size (Imsland et al. 1996). Further, the magnitude of these effects will depend on the spatio-temporal dynamics of hypoxia as well as on food availability and quality, both of which are not well known in the Gulf of Mexico. Even so, preliminary estimates suggest potential decreases in individual croaker and shrimp weight of 5 to $15 \%$ at the end of the growing season strictly from occupying suboptimal temperatures inshore and offshore of the hypoxic region (authors' unpubl. data). Croaker length distributions have remained relatively constant over the last 20 yr (Craig 2001), suggesting little or only localized effects of hypoxia on growth, however, or possibly the presence of some compensatory processes. Brown shrimp sizes have declined over the same time frame (Diaz \& Solow 1999, Craig 2001), and possibly earlier (Caillouet et al. 1980), suggesting habitat loss due to hypoxia and associated effects on growth as a potential contributing factor.

\section{Shifts in oxygen distribution in relation to hypoxia}

While temperature effects on growth energetics have received considerable attention, the effects of oxygen are not as well known. Clearly, oxygen can impose limits on the metabolic scope of organisms, as most species exhibit a minimum level of dissolved oxygen below which metabolism depends on ambient oxygen concentration (Fry 1971, Bridges \& Brand 1980). Despite avoidance of the lowest oxygen waters on the shelf, croaker and brown shrimp near the offshore hypoxic edge occupied waters of moderately low dissolved oxygen ( 35 to $60 \%$ air saturation, 1.6 to $3.7 \mathrm{mg} \mathrm{l}^{-1}$ ) with the highest densities occurring at the lowest oxygen levels nearest the hypoxic edge. In contrast, oxygen levels inshore of the hypoxic region were relatively high (>90\% saturation, 4.7 to $6.4 \mathrm{mg} \mathrm{l}^{-1}$ ), suggesting that movement inshore versus offshore to avoid low oxygen water has different implications for the oxygen levels that organisms ultimately experience.

Similar to the shifts in temperature distribution, oxygen levels near the offshore hypoxic edge are within the range where metabolism and growth are dependent on ambient oxygen concentration in other species. While the incipient limiting level of dissolved oxygen for routine metabolism differs considerably among fishes, limiting levels typically range from 20 to $50 \%$ air saturation (Hughes et al. 1983, van den Thillart et al. 1994, Maxime et al. 2000). Laboratory studies with shrimp suggest oxygen consumption is dependent on ambient concentration at $\sim 40$ to $80 \%$ air saturation, though these studies have generally been conducted with smaller postlarval and early juvenile stages rather than the larger subadults typically found on the shelf (\% air saturation where metabolism oxygen-dependent: Penaeus setiferus $\sim 73 \%$, P. schmitti $\sim 82 \%$, Rosas et al. 1997; P. monodon $\sim 44 \%$, Salvato et al. 2001). Incipient limiting oxygen levels will increase with any activity (e.g. feeding, swimming) that increases oxygen demand (van den Thillart et al. 1994, Maxime et al. 2000, Pichavant et al. 2000). The few studies that have quantified the effect of ambient dissolved oxygen on metabolic scope in fishes and shrimp report decline in scope at $\sim 40$ to $90 \%$ air saturation (van den Thillart et al. 1994, Rosas et al. 1999, Claireaux et al. 2000, Lefrancois \& Claireaux 2003). These results suggest that ambient oxygen may impose limits on available energy for croaker and brown shrimp even though organisms avoid the lowest oxygen levels on the shelf.

Hypoxia on the Louisiana shelf is most widespread from June to August with evidence that large hypoxic regions persist for at least 1 to 2 mo or longer (Rabalais et al. 2002, Craig et al. 2005). Hence, metabolic costs associated with altered temperature and oxygen distributions may persist for large portions of the growing season. The magnitude of these effects will depend on the sensitivity of metabolic scope to variation in ambient temperature and oxygen, the potential for metabolic and growth acclimation, and other factors that impact organism energy budgets (i.e. food consumption). For example, short-term increases in feeding rates associated with the emergence and impaired escape responses of hypoxia-stressed benthic prey have been reported in several systems (Rahel \& Nutzman 1994, Nestlerode \& Diaz 1998, Seitz et al. 2003), as have longer-term changes in diet and benthic community structure associated with low dissolved oxygen (Pihl 1994, Diaz \& Rosenberg 1995). Hence, changes in food availability and quality may exacerbate or compensate for the metabolic effects of shifts in temperature and oxygen reported here. Nonetheless, even small changes in abiotic conditions can have large cumulative effects over the growing season (Whitledge et al. 2002).

\section{Relationship to the hypoxic edge}

We found extremely high densities of croaker and brown shrimp near the offshore edge of the hypoxic 
region. The pattern in abundance was best characterized as an exponential decline with increasing distance from the edge (the most extreme model tested). These results suggest croaker and brown shrimp may only avoid some minimal level of dissolved oxygen resulting in the 'packing' of organisms near the hypoxic edge. Alternatively, organisms may aggregate to the edge, perhaps to take advantage of increased foraging opportunities as noted above. Whatever the case, such high densities near the hypoxic edge likely have implications for trophic interactions. If smallscale movements ( $\mathrm{m}$ to $\mathrm{km}$ ) of the hypoxic edge periodically increase the availability of benthic prey (via emergence from sediments), then these edges may be areas of enhanced foraging and growth. Alternatively, density-dependent effects or eventual prey declines (due to direct mortality from low oxygen or high foraging rates by benthic predators) may decrease the foraging value of edge habitats. Likewise, croaker and brown shrimp are prey for other upper trophic level species so that hypoxic edges may also be areas of high predation mortality, or perhaps predation refuges depending on species-specific tolerances of predators and prey to low oxygen (Breitburg et al. 1997). Similarly, brown shrimp are the target of an intense commercial fishery with peak shrimping effort during July when hypoxia is typically most severe, and croaker are an important component of the bycatch of this fishery (Diamond et al. 2000). Whether the shrimp fishery targets the high densities of shrimp on the edges of hypoxic regions is currently unknown. If so, then hypoxic edges may also be areas of intense fishery interactions with implications for both the harvest of target (shrimp) and nontarget (croaker) species. The effects of hypoxia on trophic and fishery interactions on the northwestern Gulf of Mexico shelf are the subject of ongoing investigations.

Acknowledgements. We thank the numerous personnel of the National Marine Fisheries Service Pascagoula Laboratory, the collaborating state agencies, and the Southeast Area Monitoring and Assessment Program (SEAMAP) for their efforts in conducting the research surveys on which this work is based. We thank T. Henwood, G. Pellegrin, and S. Nichols for assistance with the data. C. Stow provided statistical advice and D. Urban provided software for the Mantel regressions. D. Breitburg, S. Diamond, C. Taylor and 2 anonymous reviewers provided comments that improved the manuscript. Financial support for this project was provided by the National Marine Fisheries Service Pascagoula Laboratory and the National Oceanic and Atmospheric Administration (NOAA) Coastal Ocean Program under award \#NA160P1444 to Duke University. The data used in the preparation of this paper were collected, in part, under a grant/cooperative agreement from NOAA to the state(s) of Louisiana, Alabama, and Mississippi. The views expressed herein are those of the authors and do not necessarily reflect the view of NOAA or any of its sub-agencies.

\section{LITERATURE CITED}

Akaike $H$ (1973) Information theory and an extension of the maximum likelihood principle. In: Petran BN, Csaaki F (eds) Second international symposium on information theory. Akadeemiai Kiadi, Budapest, p 267-281

Barger LE (1985) Age and growth of Atlantic croakers in the northern Gulf of Mexico, based on otolith sections. Trans Am Fish Soc 114:847-850

Bergström BI (1991) Reproductive cycle and the effect of temperatures on oogenesis of Pandalus borealis Krøyer, 1838. J Shellfish Res 10:327-331

Bishop JM, Gosselink JG, Stone JH (1980) Oxygen consumption and hemolymph osmolality of brown shrimp, Penaeus aztecus. Fish Bull US 78:741-757

Brandt SB, Mason DM (2003) Effect of nutrient loading on Atlantic menhaden Brevoortia tyrannus growth rate potential in the Patuxent River. Estuaries 26:298-309

Breiman L, Friedman JH, Olshen RA, Stone CJ (1984) Classification and regression trees. Wadsworth and Brooks/ Cole, Monterey, CA

Breitburg DL (2002) Effects of hypoxia, and the balance between hypoxia and enrichment, on coastal fishes and fisheries. Estuaries 25:767-781

Breitburg DL, Loher T, Pacey CA, Gerstein A (1997) Varying effects of low dissolved oxygen on trophic interactions in an estuarine food web. Ecol Monogr 67:489-507

Breitburg DL, Rose KA, Cowan JH (1999) Linking water quality to fish recruitment: predation mortality of fish larvae in an oxygen-stratified water column. Mar Ecol Prog Ser 178: 39-54

Brett JR (1971) Energetic responses of salmon to temperature: a study of some thermal relations in the physiology and freshwater ecology of sockeye salmon (Oncorhynchus nerka). Am Zool 11:99-113

Brett JR (1979) Environmental factors and growth. In: Hoar WS, Randall DJ, Brett JR (eds) Fish physiology, Vol VIII. Academic Press, New York, p 599-675

Bridges CR, Brand AR (1980) Oxygen consumption and oxygen-independence in marine crustaceans. Mar Ecol Prog Ser 2:133-141

Bryan JD, Kelsch SW, Neill WH (1990) The maximum power principle in behavioral thermoregulation by fishes. Trans Am Fish Soc 119:611-621

Caddy JF (1993) Toward a comparative evaluation of human impacts on fishery ecosystems of enclosed and semienclosed seas. Rev Fish Sci 1:57-95

Caillouet CW, Patella FJ, Jackson WB (1980) Trends toward decreasing size of brown shrimp, Penaeus aztecus, and white shrimp, Penaeus setiferus, in reported annual catches from Texas and Louisiana. Fish Bull US 77 : 985-989

Claireaux, G, Webber DM, Lagardère JP, Kerr SR (2000) Influence of water temperature and oxygenation on the aerobic metabolic scope of Atlantic cod (Gadus morhua). J Sea Res 44:257-265

Coman GJ, Crocos PJ, Preston NP, Fielder D (2002) The effects of temperature on the growth, survival and biomass of different families of juvenile Penaeus japonicus Bate. Aquaculture 14:185-199

Coutant CC (1977) Compilation of temperature preference data. J Fish Res Board Can 34:739-745

Coutant CC (1985) Striped bass, temperature, and dissolved oxygen: a speculative hypothesis for environmental risk. Trans Am Fish Soc 114:31-61

Craig JK (2001) Effects of large-scale hypoxia on the distribution of brown shrimp and Atlantic croaker in the north- 
western Gulf of Mexico. PhD thesis, Duke University, Durham, NC

Craig JK, Crowder LB, Gray CD, McDaniel CJ, Henwood TA, Hanifen JG (2001) Ecological effects of hypoxia on fish, sea turtles, and marine mammals in the northwestern Gulf of Mexico. In: Rabalais NN, Turner RE (eds) Coastal hypoxia: consequences for living resources and ecosystems. American Geophysical Union, Washington, DC, p 269-291

Craig JK, Henwood TA, Crowder LB (2005) Effects of abundance and large-scale hypoxia on the spatial distribution of brown shrimp (Farfantepenaeus aztecus) on the northwestern Gulf of Mexico continental shelf. Can J Fish Aquat Sci 62:(in press)

Cripe GM (1994) Induction of maturation and spawning of pink shrimp, Penaeus duorarum, by changing water temperature, and survival and growth of young. Aquaculture 128:255-260

Darnell RM, Kleypas JA, Defenbaugh RE (1983) Northwestern Gulf Shelf bio-atlas. Minerals Management Service Report 82-04. Minerals Management Service, Gulf of Mexico, OCS Region, New Orleans, LA

Diamond SL, Cowell LG, Crowder LB (2000) Population effects of shrimp trawl bycatch on Atlantic croaker. Can J Fish Aquat Sci 57:2010-2021

Diaz RJ, Rosenberg R (1995) Marine benthic hypoxia: a review of its ecological effects and the behavioural responses of benthic macrofauna. Oceanogr Mar Biol Annu Rev 33:245-303

Diaz RJ, Solow A (1999) Ecological and economic consequences of hypoxia: Topic 2 Report for the integrated assessment of hypoxia in the Gulf of Mexico. NOAA Coastal Ocean Program Decision Analysis Series No. 17, NOAA Coastal Ocean Program, Silver Springs, MD

Eby LA, Crowder LB (2002) Hypoxia-based habitat compression in the Neuse River estuary: context-dependent shifts in behavioral avoidance thresholds. Can J Fish Aquat Sci 59:952-965

Eldridge PJ (1988) The southeast area monitoring and assessment program (SEAMAP): a state-federal-university program for collection, management, and dissemination of fishery-independent data and information in the southeastern United States. Mar Fish Rev 50:29-39

Elliott JM (1975) The growth rate of brown trout (Salmo trutta L.) fed on reduced rations. J Anim Ecol 44:823-842

Fry FEJ (1971) The effect of environmental factors on the physiology of fish. In: Hoar WS, Randall DJ (eds) Fish physiology, Vol VI. Academic Press, New York, p 1-98

Grimes CB (2001) Fishery production and the Mississippi River discharge. Fisheries 26:17-26

Hastie T, Tibshirani R (1990) Generalized additive models. Chapman \& Hall, London

Hodson RG, Fechelm, RG, Monroe RJ (1981) Upper temperature tolerance of spot, Leiostomus xanthurus, from the Cape Fear estuary, North Carolina. Estuaries 4:345-356

Hughes GM, Albers C, Muster D, Götz KH (1983) Respiration of the carp, Cyprinus carpio L., at 10 and $20^{\circ} \mathrm{C}$ and the effects of hypoxia. J Fish Biol 22:613-628

Hutchings JA, Myers RA (1994) Timing of cod reproduction: interannual variability and the influence of temperature. Mar Ecol Prog Ser 108:21-31

Imsland AK, Sunde LM, Folkvord A, Stefansson SO (1996) The interaction of temperature and fish size on growth of juvenile turbot. J Fish Biol 49:926-940

Jobling M (1981) Temperature tolerance and the final preferendum-rapid methods for the assessment of optimal growth temperatures. J Fish Biol 19:439-455
Jobling M (1994) Fish bioenergetics. Chapman \& Hall, London

Jones FV, Strawn K (1986) The effects of feeding rates on the dynamics of black drum and spot cage cultured in a heated water tank. J World Maricult Soc 16:19-31

Lefrancois C, Claireaux G (2003) Influence of ambient oxygenation and temperature on metabolic scope and scope for heart rate in the common sole Solea solea. Mar Ecol Prog Ser 259:273-284

López-Martínez J, Arreguín-Sánchez F, Hernández-Vázquez S, García-Juárez AR, Valenzuela-Quiñonez W (2003) Interannual variation of growth of the brown shrimp Farfantepenaeus californiensis and its relation to temperature. Fish Res 61:95-105

Magnuson JJ, Crowder LB, Medvick PA (1979) Temperature as an ecological resource. Am Zool 19:331-343

Manly BFJ (1991) RT: a program for randomization testing. Version 1.02. Western EcoSystems Technology, Cheyenne, WY

Mantel N (1967) The detection of disease clustering and a generalized regression approach. Cancer Res 27:209-220

Maxime V, Pichavant K, Boeuf G, Nonnotte G (2000) Effects of hypoxia on respiratory physiology of turbot, Scophthalmus maximus. Fish Physiol Biochem 22:51-59

Micheli F (1999) Eutrophication, fisheries, and consumerresource dynamics in marine pelagic ecosystems. Science 285:1396-1398

Moore D, Brusher HA, Trent L (1970) Relative abundance, seasonal distribution, and species composition of demersal fishes off Louisiana and Texas, 1962-1964. Cont Mar Sci 15:45-70

Murawski SA, Finn JT (1988) Biological bases for mixed species fisheries: co-distribution in relation to environmental and abiotic variables. Can J Fish Aquat Sci 45:1720-1735

Nestlerode JA, Diaz RJ (1998) Effects of periodic environmental hypoxia on predation of a tethered polychaete, Glycera americana: implications for trophic dynamics. Mar Ecol Prog Ser 172:185-195

NRC (National Research Council) (2000) Clean coastal waters - understanding and reducing the effects of nutrient pollution. National Academy Press, Washington, DC

Patella F (1975) Water surface area within statistical subareas used in reporting Gulf coast shrimp data. Mar Fish Rev 37: $22-24$

Pendleton EC (1973) Effects of temperature on growth, feeding efficiency, and thermal tolerance of juvenile croakers (Micropogonias undulatus). Master's thesis, North Carolina State University, Raleigh, NC

Pichavant $\mathrm{K}$, Person-Le-Ruyet $\mathrm{J}$, Le Bayon N, Sévère A and 5 others (2000) Effects of hypoxia on growth and metabolism of juvenile turbot. Aquaculture 188:103-114

Pihl L (1994) Changes in the diet of demersal fish due to eutrophication-induced hypoxia in the Kattegat, Sweden. Can J Fish Aquat Sci 51:321-336

Pihl L, Baden SP, Diaz RJ (1991) Effects of periodic hypoxia on distribution of demersal fish and crustaceans. Mar Biol 1080:349-360

Ponce-Palafox J, Martinez-Palacios CA, Ross LG (1997) The effects of salinity and temperature on the growth and survival rates of juvenile white shrimp, Penaeus vannamei, Boone, 1931. Aquaculture 157:107-115

Priede IG (1985) Metabolic scope in fishes. In: Tytler P, Calow P (eds) Fish energetics: new perspectives. John Hopkins University Press, Baltimore, MD, p 33-64

Rabalais NN, Turner RE (2001) Hypoxia in the northern Gulf of Mexico: description, causes and change. In: Rabalais NN, Turner RE (eds) Coastal hypoxia: consequences for 
living resources and ecosystems. American Geophysical Union, Washington, DC, p 1-36

Rabalais NN, Turner RE, Wiseman WJ (2002) Gulf of Mexico hypoxia, a.k.a., 'The Dead Zone.' Annu Rev Ecol Syst 33: 235-263

Rahel FJ, Nutzman JW (1994) Foraging in a lethal environment: fish predation in hypoxic waters of a stratified lake. Ecology 75:1246-1253

Railsback SF, Rose KA (1999) Bioenergetics modeling of stream trout growth: temperature and food consumption effects. Trans Am Fish Soc 128:241-256

Rester JK, Sanders N, Hanisko D, Thompson PA (2004) SEAMAP environmental and biological atlas of the Gulf of Mexico, 2001. Gulf States Marine Fisheries Commission 118, Ocean Springs, MS

Rosas C, Sánchez A, Díaz-Iglesia E, Brito R, Martinez E, Soto LA (1997) Critical dissolved oxygen level of Penaeus setiferus and Penaeus schmitti postlarvae ( $\left.\mathrm{PL}_{10-18}\right)$ exposed to salinity changes. Aquaculture 152:259-272

Rosas C, Martinez E, Gaxiola G, Brito R, Sánchez A, Soto LA (1999) The effect of dissolved oxygen and salinity on oxygen consumption, ammonia excretion and osmotic pressure of Penaeus setiferus (Linnaeus) juveniles. J Exp Mar Biol Ecol 234:41-57

Salvato B, Cuomo V, Di Muro P, Beltramini M (2001) Effects of environmental parameters on the oxygen consumption of four marine invertebrates: a comparative factorial study. Mar Biol 138:659-668

Schick RS, Urban DL (2000) Spatial components of bowhead whale (Balaena mysticetus) distribution in the Alaskan Beaufort Sea. Can J Fish Aquat Sci 57:2193-2200

Seitz RD, Marshall LS, Hines AH, Clark KL (2003) Effects of hypoxia on predator-prey dynamics of the blue crab Callinectes sapidus and the Baltic clam Macoma balthica in Chesapeake Bay. Mar Ecol Prog Ser 257:179-188

Taylor DL, Collie JS (2003) A temperature- and sizedependent model of sand shrimp (Crangon septimspinosa) predation on juvenile winter flounder (Pseudopleuronectes americanus). Can J Fish Aquat Sci 60:1133-1148

Taylor DL, Eggleston DB (2000) Effects of hypoxia on an estuarine predator-prey interaction: foraging behavior and

Editorial responsibility: Jennifer Purcell (Contributing Editor), Anacortes, Washington, USA mutual interference in the blue crab Callinectes sapidus and the infaunal clam prey Mya arenaria. Mar Ecol Prog Ser 196:221-237

Taylor JC, Miller JM (2001) Physiological performance of juvenile southern flounder, Paralichthys lethostigma (Jordan and Gilbert, 1884), in chronic and episodic hypoxia. J Exp Mar Biol Ecol 258:195-214

van den Thillart G, Dalla Via J, Vitali G, Cortesi P (1994) Influence of long-term hypoxia exposure on the energy metabolism of Solea solea. I. Critical $\mathrm{O}_{2}$ levels for aerobic and anaerobic metabolism. Mar Ecol Prog Ser 104:109-117

Venables WN, Ripley BD (1999) Modern applied statistics with S-plus. Springer-Verlag, New York

Villarreal H, Ocampo L (1993) Effect of size and temperature on the oxygen consumption of the brown shrimp Penaeus californiensis (Holmes, 1900). Comp Biochem Physiol A 106:97-101

Wang B, Xinghua M, Rubao J, Hongjie L (1997) Study on growth characteristics of red drum (Sciaenops ocellatus). Mar Sci Bull 16:36-42

Wannamaker CM, Rice JA (2000) Effects of hypoxia on movements and behavior of selected estuarine organisms from the southeastern United States. J Exp Mar Biol Ecol 249: 145-163

Ward R, Blandon IR, King TL, Bass PR, Beitinger TL (1993) Comparisons of critical thermal maxima and minima of juvenile red drum (Sciaenops ocellatus) from Texas and North Carolina. Northeast Gulf Sci 13:23-28

Whitledge GW, Hayward RS, Rabeni CF (2002) Effects of temperature on specific daily metabolic demand and growth scope of sub-adult and adult smallmouth bass. J Freshw Ecol 17:353-361

Wu RSS (2002) Hypoxia: from molecular responses to ecosystem responses. Mar Pollut Bull 45:35-45

Wyban J, Walsh WA, Godin DM (1995) Temperature effects on growth, feeding rate and feed conversion of the Pacific white shrimp (Penaeus vannamei). Aquaculture 138:267-279

Zein-Eldin ZP, Griffith GW (1969) An appraisal of the effects of salinity and temperature on growth and survival of postlarval penaeids. FAO Fish Rep 57:1015-1026

Submitted: July 12, 2004; Accepted: November 23, 2004 Proofs received from author(s): May 30, 2005 